DOI: $10.24143 / 2073-5537-2021-2-140-156$

УДК 334.7.012.64(669):578.7

\title{
COVID-19 ECONOMIC RESPONSE MEASURES AND ENTREPRENEURIAL ACTIVITIES: A STUDY OF MICRO-ENTERPRISES IN NIGERIA
}

\author{
Obi Chinazor Franca \\ Alex-Ekwueme Federal University Ndufu-Alike, Ikwo, \\ Ebonyi State, Nigeria
}

\begin{abstract}
Nigeria witnessed an economic downturn in 2009 due to the global financial crisis and in 2016 as a result of the global oil price crash. The Nigerian economy was resuscitating from the economic recession before the emergency of the COVID-19 pandemic and its curtail measures. Most private and government firms laid-off their workers, while others had their staff salaries. The sustaining business operations in this era may be extremely difficult due to lack of funds for selfemployment, start-up ventures, innovations or new market opportunities. With the help of the Central Bank the government rowed out some monetary and fiscal measures referred to in the study as Economic Responses Measures (ERM). The aim of the study is to examine the relationship between COVID-19 ERM and the Entrepreneurial Activity (EA) of micro business. It has been stated that COVID-19 ERM provide innovations, self-employment, start-up and new market creation activities of micro-enterprises in Nigeria. An exploratory survey was done on 294 randomly selected samples from micro-enterprises (retail, ICT, manufacturing and artisans) across the six geopolitical zones in Nigeria. The result proves empirically that COVID-19 ERM does not have a significantly positive relationship with the EA of micro-businesses in Nigeria. The implication of this finding therefore suggests that many micro-businesses may not have accessed these ERM or do not embark in EA. There is highlighted the importance of government support to micro-businesses and also provided new dimensions for the measures of micro-business EA.
\end{abstract}

Key words: COVID-19 economic response measures, innovation, self-employment, start-up ventures, new market creation.

For citation: Obi Chinazor Franca. COVID-19 economic response measures and entrepreneurial activities: a study of micro-enterprises in Nigeria. Vestnik of Astrakhan State Technical University. Series: Economics. 2021;2:140-156. (In Russ.) DOI: 10.24143/2073-5537-2021-2-140-156.

\section{Introduction}

Before the emergency of the global pandemic the Nigerian economy was lethargically resuscitating with the headwind of 2016 economic recession caused by the global oil price crash. Eventually, with the outbreak of COVID-19 first index case in Nigeria on $27^{\text {th }}$ February 2020 from the Italian citizen in Lagos state, the global health threat of Coronavirus medically known as COVID-19 caused by SARS-CoV-2, a public health crisis triggered the global economic crises. The virus which broke out from the Wuhan area of China in late 2019 slowly spread to other countries of the world with thousands of fatalities in each country. As a result, the World Health Organisation (WHO) on $11^{\text {th }}$ of March, 2020 declared the disease "pandemic" following the death toll, its rapid spread and higher infection rates across the globe. COVID-19 pandemic may be threatening, but may create opportunities for many micro-enterprises [1, 2]. The IMF (2020) [3] and World Bank (2015) [4] predicted world economic recession and a shrink by at least $3.4 \%$ of the Nigerian economy. The WHO listed Nigeria among other African countries identified as high-risk for the spread of the virus following the Nigerian first index case. It is an empirical truth that the Nigerian economy will no longer depend on the collapsed oil revenue to grow the economy and, on the other hand, to sustain business operations in the COVID-19 pandemic period, which may be extremely difficult for many businesses [3]. As a result, most families and individuals are expected to at least engage in micro-businesses, as it is quite easy to venture into and requires a little finance, little or no registration, etc. [5].

A micro-enterprise in Nigeria's context is defined as any enterprise with a working "asset not more than five million naira including working capital but exclude the cost of land and with not up to 10 employees" [6]. Micro-businesses include businesses like saloons, pet-retailers, barbers', roadside 
sellers, restaurants, hawkers, artisans, truck pushers, etc.). The scholars and international organizations note that about $90 \%$ of the world business are micro-, small and medium enterprises and in Nigeria they contribute about $50 \%$ of GDP and about $53 \%$ of the employments sectors [7]. They adapt to any change in the business environment locally or globally. Quick responses are expected from microbusinesses as they have the innovative advantage over the large firms, which is embedded in their less bureaucratic decision to introduce a new product or services. They are more flexible and can proactively respond to changes in the market than larger firms [8]. The dynamic nature of this sector also makes it vulnerable to a high mortality rate and lack of performance [7] occasioned by sudden shifts in economic policy, global trends, global shocks in international markets and many unforeseen situations. $70 \%$ of the large enterprises started as micro-businesses [9]. Many micro-enterprises are more vulnerable to the market failures, policy inefficiency and inconsistency than large firms. This happens because they are managed at the discretions of one person or family business; they lack formal procedures of business operations and hardily keep account or record of their transactions. As a result, they are easily neglected by the government and policymakers [9]. The analysis shows that about $56 \%$ of SMEs are expected to quit the business if crises continued in the next six months [10]. Therefore, for continuality and survival the micro-enterprises need to devise means of re-evaluating their current structure in light of the current reality to explore opportunities to prepare for the new reality and remain relevant. Subsequently, Nigeria needs economic recovery programs and policies which have the aim of creating jobs, providing support for the poorest and most vulnerable members through SME.

Fornaro and Wolf (2020) [11] suggest the drastic policy interventions of both monetary and fiscal measures to prevent the negative impact of COVID-19 on the businesses. The Nigerian government therefore through the central bank at the "Growth 2.0 meeting held at Abuja and the Bankers" Committee Meeting" held at Lagos rowed out some monetary and fiscal measures referred in the study as Economic Responses Measures (ERM) to tackle the impact of the pandemic and to support the microenterprises. According to the survey conducted in Nigeria in 2020, the majority of business owners did not hold a positive opinion on the government ERM; fear was expressed on the sharing formula of grants and intervention funds, and the implementations of these ERM in the Nigeria states. The survey shows that $23.8 \%$ considered these interventions grossly inadequate, $43.9 \%$ see it as inadequate, and $17.5 \%$ were indifferent about it, while $14.4 \%$ admitted that it met their business need. The economic analysist has predicted that there are limitations to the success of that ERM that can be recorded when demand shocks are combined with supply shock [12], hence, the speed, quality and sustainability of Nigeria's economic recovery will be determined by the effectiveness of its government's response. The economic consequence of COVID-19 pandemic calls for the urgent policy responses to keep the economy afloat. The study, therefore, assumed that businesses, especially the micro-enterprises and families, who were supposed to be the main beneficiaries of these ERMs, were able to capitalize in the opportunity to create invaluable activities through entrepreneurship.

Entrepreneurship involves activities termed as entrepreneurial activities (EA) which are associated with self-employment, start-up venture, novelty and the creation of market, processes and/or new products. The EA - no matter how it is conceptualized - is saddled with the responsibilities of new products and processes development, provision of employment opportunities to the unemployed and development of the skilled and semi-skilled workforce, discovering new market and replacing inefficient incumbent [8]. EAs, therefore, through the utilization of opportunities, create values that can boost the economy and eventually place Nigeria at the same level as other developed countries of the world. The analyst has predicted that poorly designed implementations of the ERMs can have the negative and long-lasting consequences for entrepreneurs [3,13]. GEM surveys confirmed that the level of EA varies among countries at a fairly constant rate, it requires time and consistency of policy interventions to build factors that contribute to entrepreneurial activities and create opportunities too. Besides the proxies for entrepreneurial activities vary both at the individual, a firm or a contextual location, therefore, the analysis of the same proxies will not produce any different results under different dimensions, sector, institutions or contextual location being studied [14]. The study, therefore, is built on and contributes to the body of knowledge on entrepreneurship in the developing country. Although there are different contributions on entrepreneurship in Nigeria, this is the first empirical study to examine the impact of the COVID-19 ERM on Entrepreneurial Activities (EA). Wennekers, Van Stel, Carree and Thurik (2010) [15] argued that the starting point of EA is at a micro level. The study con- 
centrates on the micro-level entrepreneurship activities factors focusing on micro-enterprises where a firm transforms the COVID-19 ERM to entrepreneurial actions which can trigger self-employment, start-up, innovation and job creation in Nigeria (Al-Ghwell, 2020).

The main motive of this research is driven by a strong personal interest in entrepreneurial activities as a means able to bring about economic growth to the poorest/underdeveloped part of the world. It is also driven by the burning desire to contribute an empirical study to the toiling micro-enterprises struggling to survive in this pandemic period, hence the choice of the problem to unveil the potential of entrepreneurship in Nigeria, if these measures will be well implemented. The study provides factors shaping the extent of entrepreneurial activity, hence it provides the insights into how policy could be used to promote entrepreneurship. To encourage the government and policymakers to develop favourable conditions that motivate and support micro-enterprises' growth, it is necessary to form the supportive system and methods for potential start-up, invest on micro-enterprises and business owners, to create and exploit the opportunities around using local materials for manufacturing the required and valuable goods for the bottom of the pyramid at affordable prices while generating employment for the vast majority of unemployed youth and competing with the international market.

\section{The objectives of the Study}

1. To examine whether there is a significant positive relationship between EA and innovative activity of micro-enterprises in Nigeria.

2. To find out whether there is a significant positive relationship between COVID-19 ERM and job-creation activity of micro-enterprises in Nigeria.

3. To establish whether there is a significant positive relationship between COVID-19 ERM and the venture start-up activity of micro-enterprises in Nigeria.

4. To survey the significant positive relationship between COVID-19 ERM and market creation activity of the micro-enterprises in Nigeria.

\section{Literature Review}

\section{Definitions and Meaning of Entrepreneurial Activity (EA)}

Entrepreneurship, therefore, is associated with Entrepreneurial Activity (EA). The study views EA as the efforts of the firms in creation or expansion of economic and social value. The economic value shows a financial activity, output, economic growth, productivity growth, sales growth, return on investment, while social values involve poverty reduction, job creation, etc. The entrepreneurial activity is prompted by the opportunities alertness and exploitation in a particular environmental setting.

Entrepreneurship and Entrepreneurial Activities (EA) are used interchangeably; however, entrepreneurship breeds entrepreneurial activities. Entrepreneurship involves a range of activities and level of analysis that no single definition is conclusive $[16,17]$. The economists view entrepreneurs based on their activities and define them as persons who combine resources, labour, materials and other assets in order to create values greater than before at the market. The Global Entrepreneurship Monitor (GEM) defines entrepreneurship as following:

“...any attempt at new business or new venture creation, such as self-employment, a new business organization, or the expansion of an existing business, by an individual, a team of individuals, or an established business" [18];

"...one who creates a new business in the face of risk and uncertainty to achieve profit and growth by identifying significant opportunities and assembling the necessary resources to capitalize on them" [19].

The business of entrepreneurs is doing something different, hence not all businesses are entrepreneurial and not all entrepreneurs are entrepreneurial [20]. Entrepreneurs can be motivated by either the necessity or opportunity [20]. Opportunity entrepreneurship is the bedrock of any free enterprise economy that wants to grow its economy and hence reduce the poverty level of its citizenry [21]. Entrepreneurs differ in the ability to exploit or create business opportunities through micro-enterprises. Kirzner (1997) [22] views the entrepreneurial activity as the discovery of opportunities and subsequently the creation of new economic activity via the creation of firms and innovative activities. The necessity entrepreneurs venture into businesses to avoid being ideal since COVID-19 prompted the closure of many businesses, downsizing of many staff, and innovative ways of business operations. 
However, entrepreneurial activity has also been defined by scholars:

EA was defined as "the dynamic process of identifying economic opportunities and acting upon them by developing, producing and selling goods and services" [23].

Fostering Entrepreneurship defined EA as the ability to marshal resources to seize new business opportunities. EA is seen as an action guided toward the responding or generating, development, transmitting, and amending an idea where necessary. Entrepreneurial activity results in selfemployment, shareholders, society (taxes, and other payments, job creation), customers (through superior value propositions), and other stock holders in the contextual entrepreneurial ecosystem. The micro and macro-economic level impacts on the entrepreneurial value creation and exchange together in a particular contextual setting. The success of the entrepreneurial activity is based on the strength of perceived opportunity, innovation capabilities and creative resources. Our study, therefore, defines EA based on what they do rather than what they achieve or who they are. EA involves exploiting or creating an opportunity for a firm to engage in innovative activities, venture into new or improved businesses, engage in market creation and create jobs and valuable products/services that create wealth for the entrepreneurs and the stakeholders. Bögenhold, Heinonen and Akola (2014) [24] argue that entrepreneurship can only be measured by their activities to the societies, while Wiklund and Shepherd (2005) [25] view entrepreneurship as behaviour and activities of an individual or a firm. EA is not dependent upon the entrepreneurship only as many studies have based entrepreneurship to new business owners who are innovative. This is because entrepreneurs may demonstrate entrepreneurship without being the owners of the firm. The OECD [9] argues that entrepreneurship is an activity of identifying economic opportunities, developing, producing and selling the products and services. EA is an output of the interaction of an individual/firm's perception of an opportunity and capability in a particular context in which the individual/firm is located.

Entrepreneurs in the quest to engage in self-employment, innovation, job creation, start-up venture and create new market are objective, unique and are risk-bearers in discovering and exploring opportunities in the COVID-19 ERM. The entrepreneurs opine for pre-existence of all possible opportunities. This enables an entrepreneur to engage in perfectly rational and optimal decision making to profoundly "search and select" among already existing COVID-19 opportunities. This is because the explicit nature of opportunities allows entrepreneurs to engage in "Search and Comparison" between different ERM [26]. On the other hand, the entrepreneurs have to combine information about the COVID-19 pandemic conditions, different responses measures and their previous knowledge [27] to create economic or social values that can boost the economy. Many EA create valuable opportunity out of the pandemic crises that boost their income and that of others. COVID-19 crises created the opportunity for many to make wealth through both government and individual palliatives, learn how to use their phones for online businesses, etc. others go beyond these existing opportunities to create their opportunity. For instance, while the importation of goods and services become difficulty during the pandemic, many EA grabs the opportunity to embark in quality production of goods and services that consumers hardily know that they are local. This can result in continues patronage of such goods.

Firms with marketing insight have intuition and understand what is occurring in current and future markets. Firms with marketing insight proactively think deeper and more accurately on a consistence basis instead of retorting to the occurrences in the market. Having a marketing insight requires a firm to greatly involve in environmental scanning and marketing experimentation. These help in providing information to the firm. There is no market for opportunity unless it is recognized and exploited [20,28]. Opportunity recognition and exploitation have been proved to be the basis of entrepreneurial innovativeness and nations' wealth creation. A successful entrepreneur must have the capabilities to organize resources and exploit the opportunity in such a way as to create value in the market. Also, entrepreneurial skills and capability become a waste without opportunities. The formation of a nation's wealth relies on the firms' competitiveness which is a product of the entrepreneurial skills and capabilities.

\section{Entrepreneurial Activities of Micro-Enterprises}

Self-Employment: Unemployment has remained the most critical challenge faced African countries including Nigeria [17]. The self-employment reveals the rate with which individuals are motivated to engage in businesses. Self-employment rate is defined as a percentage of the labour force (the total number of employed persons plus unemployed). It shows the percentage of 18-64-aged population who 
are currently self-employed for more than 3 and half years. The federal government reports that the growth of micro-enterprises in Nigeria could unlock up to 12.6 million jobs if a progressive transformation strategy is put place.

Innovation is born out of crises like COVID-19 pandemic. It is defined as bringing new products or changes in the existing ones, using new methods to decrease costs, developing a firm's system, recognizing the role of the market and increasing productivity [8]. It, therefore, involves any form of change or newness, imitating foreign or local products, introducing new ways of production, or using new resources or technology in production which can lead to launching a new product in the market place. It shows the percentage of entrepreneurs who indicated that their product or service is new to a least to some customers. It opens the lead way to new technology adoption by firms to catch up with the prevalent technology frontier for sustainable economic growth.

Job-Creation: Providing decent work for the citizens has remained one of the pressing issues around the developing countries, not just Nigeria alone (see CBN [6]). Small-scale firms contribute to the employment of labour. SMEDAN and NBS (2013) [7] observed that Lagos State has the highest number of small and medium enterprises $(11,663)$. The total number of persons employed by the MSMF sector as in December 2013 stood at 59,741,211, representing 84.02\% of the total labour force. They create more jobs per unit of enterprises; this ensures the large numbers of unemployed youth to be employed by these firms.

The Start-Up Ventures indicate the rate with which new businesses are been introduced in these zones. This found through the number of business that is below one year. Recognizing and exploiting the appropriate opportunity for new businesses from among others is the most important characteristic of an EA [22]. Start-up venture requires some activities which include acquiring and integrating resources attributes like gathering resources, integrate opportunities with available resources attributes that enable firm creation like (new venture development and the creation of a business that adds value).

Market Creation Activity: The most successful way to create a new market is to create novelty with a target to address a need in the marketplace or firms cultivate an underserved clientele with established products. Nigeria has the $2^{\text {nd }}$ largest economy in sub-Sharan Africa. Nigeria has the largest attractive entrepreneurial and consumer market in Africa with the population of about 170 million. Many entrepreneurs, however, identify opportunity as the motivating factor for firm creation. This creates heterogeneity of beliefs about the value of resources. The large domestic market in Nigeria also provides entrepreneurs with opportunities for business growth and expansions across industries. New market creation is a result of firms' activities, it has not just emerged. Firms create goods internally and create market externally for potential customers. It appears when firms correctly sense a latent needs and communicate their solution to that need. Entrepreneurial opportunity results in creative destruction based on market disequilibrium which generally refers to situations that hold potentials for the new economic value that impacts a nation's economy [29]. Marketing creation implies firms' wiliness in detaching from the current processes, method and activities to create and envisage mental pictures of what is or what is not presented and has never been experienced. It gives room for innovative ideas.

\section{The COVID-19 ERM and Entrepreneurship Activities}

The COVID-19 pandemic negatively impacts on both developed and underdeveloped countries of the world. The findings of Sedlacek and Sterk (2020) [30] conclude a significant decline and a strong association between decline in business registration and start-up venture and COVID-19 pandemic and in New York, business registration declines by 50\% between March-June compared to the same period in 2019. Gauthier, Penzel, and Morelix (2020) [31] also observed a substantial drop in the risk finance for innovation in China by $\$ 28$ billion. From the survey of 5800 USA firms, only $75 \%$ had two months of liquidity at hand [32] while Djankov (2020) [33] reports that the median firm runs out of liquidity in two to five months within this period. Naudé [10] observed a drastic fall in new business registration following the pandemic. A scholar and an international body warned therefore that

"It will intensify the economic stagnation that has already set in within most advanced economies, and whose beginnings can be traced back the 1970s" [10];

"... a 20 per cent decline in the number of new firms - a drop similar to the one experienced during the global financial crisis - leads to an employment loss of 0,7 per cent of aggregate employment 3 years after the shock, and still of 0,5 per cent 14 years after" [21]. 
However, the extent of this impact depends on the implementations and successfulness of response policies in particular contextual setting and the level and shape of the recovery after the crisis like the V-shaped, U-shaped and L-shapes [10]. For instance, the USA has experienced a U-shaped recovery after the financial crises (2009-2010) [34]. Fairlie (2020) [5] in USA's Current Population Survey (CPS), comments on the decline in the active business owners' by $22 \%$ between February and April, 2020.

The COVID-19 crises affect the global economy, international trade, macro and micro-economic indicators and financial markets [13]. Most governments, especially the developed countries like USA and UK, responded by offering fiscal incentives packages which include, among others, welfare payments to citizens and monetary loan relief to help businesses. There were also spillovers to poor and developing countries like Nigeria that had a weak public health infrastructure and non-existing welfare programs. Countries like China rolled out monetary support to their citizens to buy businesses abroad. Some of the ERM provided by Nigeria government include the monetary policy measures of loans, moratorium on debt repayment. A year extension of a moratorium on principal repayment for CBN intervention facilities, reduction of the interest rate on interventions, the 50 billion nairas targeted at household, micro- and small businesses, offering grants, 100 billion naira intervention fund in healthcare, 1 trillion in loans to boost local manufacturing and production across critical sectors, unified exchange rate system for inter-bank to ease pressure on FOREX earning, the official rate of 360 nairas to a dollar etc. and the fiscal policy which involves government spending: reduction on the crude oil benchmark price, the commencement of three months repayment moratorium for TradeMoni, MarketMoni and FarmerMoni loans.

With the disastrous impacts on economy and labour market shock affecting supply (production of goods and services), demand (consumption and investment) response on the economy: the poor businesses, performances and survivals are expected, as life turned to exogenous shock to many economic actors, especially the organizations, both formal and informal [35]. Most private and government firms laid-off workers while others had their staff salaries slashed. This deteriorating condition triggered Nigeria losing billions in revenues and, so, a deteriorated and contracted economic growth.

The national budget was affected too. The nation in order to retrieve and grow the macroeconomic expects significant revenue of N8.24 trillion from the proposed 2020 national budget. The budget was based on the revenue from oil which was estimated to accounts for about $90 \%$ of the foreign exchange, and $11.8 \%$ of GDP and about $31 \%$ of the 2020 Nigerian budget, which was a $20 \%$ increase of the 2019 budget figure of the fiscal year. The Nigerian 2020 budget indicators have oil volume of $2.18 \mathrm{~m}$ barrel per day, oil benchmark of $\$ 59$, the N305 exchange rate of dollar to naira, GPD growth rate of $2.93 \%$ and the inflation rate of $10.81 \%$ [6]. As a result of the COVID-19 pandemic, witnesses a sever deteriorating economic setback: the exchanged rate rose to about $\$ 440$ to naira and the economic analysis had predicted a fall in the Nigeria GDP from 3.2 to $2 \%$ [7] due to the disruption of the global supply chain, the decline in the FDI flows, capital flight, and domestic financial market tightening, the slowdown in investments, deterioration in commodity prices leading to fiscal pressure of economic power, and the depreciation of naira leading to the high cost of imported goods and raw materials. These rendered the 2020 budget obsolete, hence a new budget has to be planned to align with the crude oil revenue. Analysist has predicted that the economic impact of COVID-19 can be limited, short-term and long term and manageable too [5]. The economic analysis had predicted a fall in the Nigeria GDP from 3.2 to $2 \%$ due to the COVID-19 pandemic. The business loans and the financial assistance are expected assist micro-businesses while tax payment postponing ensures liquidity, however, these should not compensate the micro-enterprises losses [31,36]. COVID-19 affects borrowers' capacity to service loans, result in depressed banks' earnings and eventually weakened bank soundness and stability. Banks find it difficult to borrow to investors since the pandemic situation and policy limits repayment of already loans. This is because, although ERM may help micro-businesses in a shortterm to cover up their expenses, their debt will rise which only increase their problems [37]. Many have argued that the assistance is wrongly targeted or due to administrative hurdles such ERM may end up largely in the hand of large companies with micro-businesses struggling to get access to support [5]. The aftermath of this is a great competition between the larger firms that are self-supportive and microbusinesses relying on government support $[3,38]$. 


\section{Research Methodology \\ Data collection and procedure}

This study adopts the exploratory and quantitative survey design. Its main objective was to analyse the impact of COVID-19 ERM on EA dimensions: innovation, job creation, start-up ventures and market creation. A mail questionnaire was designed to ask for the firms' owner or their managers' perception on the selected variables of the study. The study referred to micro-enterprises in the six Geopolitical Zones in Nigeria as a case study. The study makes use of micro-enterprises in manufacturing sectors (bakeries, pure water, food and beverages), Artisans (welders, barbers, carpenters, hairdressers, and tailors), ICT (cyber café, business centres, etc.) and retail and whole sellers (restaurants, retail shops and supermarkets). The total number of micro-businesses in Nigeria is 36,994,578 according to SMEDAN and the National Bureau of Statistic Collaborative Survey: Selected Findings (2013). Microbusinesses barely get to their peak as many of them do not survive beyond three years of establishment [39]. This shows that firms go through different stages of growth known as life cycles. Each business has to start, then grow while facing various challenges and crises peculiar to it, then mature and finally decline [21]. Hence, the total number of newly formed businesses described in the study is businesses under (1 month - 3 years). However, those that access the ERM in Nigeria as assumed in the study is not known. The population we suppose to rely on is infinite since there is no accurate data for these. This, therefore, implies that it can only be determined through investigations. Based on the circumstances and conveniences, consideration time, cost and precision of selecting and reaching the newly formed business owners within the six-geopolitical zones in Nigeria [40]. The researcher, therefore, used the Top man's formula $\times 2$ to determine the appropriate sample population to avoid being biased:

$$
N=\left[\frac{Z^{2} X P Q}{E^{2}}\right] X 2,
$$

where $N$ is the sample population for newly formed business in Nigeria; $Z$ - a constant figure of (1.96); $P$ is the probability that the micro-business is new $(0.5)$ while $Q$ is the probability that micro business is not new (0.5) and $E$ is the allowed error amount (90.05). Using the inferential judgement and conveniences, $p$ will be represented with (0.5) while $Q$ will be represented by (0.05). This implies that the researcher assumed a 50-50 per cent chances (equal chance) of each selected business being either new and accessing ERM or not new and not accessing ERM. This $N$ was doubled to get a larger sample from the population.

So we have $N=\left(1.96^{2} \times 0.5 \times 0.5\right) / 0.05^{2}=384.16 \times 2=768$ approximately.

Average distribution was used to select the number of questionnaires that should be distributed in each zone to erased unfair representation. Hence,

$$
X=n / k,
$$

where $X$ is the sample size to be distributed in each zone; $n$ is the calculated sample size (768) and $k$ is the number of scope coverage.

$X=768 / 12=64$ micro-businesses in each zone in Nigeria.

This information was collected using a five-point scale $(1=$ grossly low, $2=$ low, $3=$ indifferent, $4=$ high and $5=$ grossly high) in response to statements about these variables. The questionnaire was tested using five micro-enterprises to ensure that the survey content and measurement scales were clear, valid and appropriate. Following some modifications, a second pre-test was carried out with ten micro-enterprises managers, to minimize the question ambiguity and difficulty in responding. This also confirms the content validity of the survey. Based on their responses, some adjustment was made. The data collection was started to enable proper business activities to commence.

These sectors were conveniently selected to enable the researcher sent and get information from the managers of these firms via email. Since the study deals with micro-businesses random sampling was employed in administering the questionnaire around the states in each zone. Out of the 768 random chosen micro-enterprises, about 302 were able to respond. Only the valid questionnaire of 294 was used for the analysis. 


\section{Variables and Measurement Scales}

The activities of entrepreneurs had been a multidimensional concept which depends on the focus of the study. The theoretical perspectives adopt led to broad arrays of different EA definitions. Scholars lack agreement on the measure of entrepreneurial activity [29]. Also, the measurement of EA in a particular county is determinant of the level of the analysis used, hence, the Total Early Stage Entrepreneurial Activity (TEA) index is built around direct measures of individual firm activities independent start-up, the current job involves start-up, current owner/manager of business. These do not include other indirect or environmental indicators of activity that have a real impact on firms in this COVID-19 era. EA has been defined according to the ventures' life cycle phase (nascent, new venture, established venture and discontinuation), the types of activity (high growth, innovation, internationalization), and the sectors of the activity by (TEA) as Social Entrepreneurial Activity (SEA), Employee Entrepreneurial Activity (EEA). The GEM survey also confirms that EA in different forms (nascent, start-up, intrapreneurship) is positively correlated to economic growth, but that this relationship depends on the phase of economic development of the country [41]. The Eurobarometer survey in Europe reports that self-employment, the number of enterprises per 1000 peoples and the percentage of economically active businesses was a preferred metric, while Kuckertz, Braendle, Gaudig, Hinderer, Reyes, Prochotta, Steinbrink and Berger (2020) [42] observed that some studies were based on individual opportunity entrepreneurial activities like the International Labour Organization (ILO) that used the proxy of selfemployment. This defines entrepreneurship as a career choice and willingness of an individual to be active entrepreneurs, although, this ignores firm activities of intrapreneurs within an established organization, others focused on the firm-level activity like the Global Entrepreneurship Monitor (GEM) used start-up venture rate and entrepreneurs who have businesses less than 42 months old which ignore business owners' activity. Some used country-level entrepreneurial activity like the World Bank measures the registration of new firms which involves the level of firm creation within a country; this has been proven to be affected by the contextual issues of favourable and unfavourable macroenvironmental issues. However, many studies adopting these measures alone have established a lack of clear empirical evidence of whether OEA drives economic growth, productivity and employment, hence, the confirmation of a mix results and also a u-shaped relationship between EA and GDP [10]. EA is closely related to activating like job creation, innovation and start-up ventures and knowledge spillover. Entrepreneurial firms engage in innovation, create employment opportunities that translate to economic growth [19]. Innovation and start-up firms are the most vital source of new jobs and hence, it is seen as the valuable measure of EA [43]. These variables are subjectively measured.

\section{Controls}

We include the firm size, age and industry type as control. The age, size and industry of an enterprise are very important factors in accessing government responses measures. Firm size was indicated by the number of employees. Firm age was measured by the number of years the firm has been in operation (1 month - 3 years). There was a possibility that REM may not have equal accessibility by micro-enterprises in the different industries, so, respondents were asked if their sector involves manufacturing, artisans, Information and Communication Technology (ICT) and retail businesses.

\section{Data Analysis}

The table below provides information about the respondents' demographic characteristic as well as the organizational characteristic. Out of the total respondents, 132 were male and 162 were female. This indicates that there were more females than the males that started a new micro business in this COVID-19 area. The study also shows that most of the businesses used for the analysis are about 2 year-old ones (16.3\%), while those of 1 year make $45.2 \%$, hence, they are still at the formation stage while the percentage of newly formed businesses after the lockdown was just $7.7 \%$. However, the resulting proof that most of these formed businesses do not survive for a long period as those within the range of 3 years and above is $16.7 \%$. The percentage of reviving businesses $(41.9 \%)$ shows that most of the businesses are still on the formation stage before the COVID-19 while only very few $(11.7 \%)$ started from scratch with ERM benefits. Many businesses formed a partnership to survive $(31.6 \%)$ while the finding indicates that many business owners sold their businesses as (16.5\%) (Table 1). 
Socio-demographic Data of the Respondents $(n=394)$ (Survey Research, 2021)

\begin{tabular}{|l|l|c|c|}
\hline \multicolumn{1}{|c|}{ Variables } & \multicolumn{1}{|c|}{ Response Label } & Frequency & Percentage \\
\hline \multirow{2}{*}{ Gender } & Male & 132 & 45 \\
& Female & 162 & 55 \\
\hline \multirow{5}{*}{ Age of business } & 1 months - 11 months & 52 & 17.7 \\
& 1 year - 1 year 11 months & 60 & 45.2 \\
& 2 years - 2 years 11 months & 49 & 16.3 \\
& 3 years and above & 122 & 16.7 \\
\hline \multirow{5}{*}{ Numbers of employees } & $0-2$ & 70 & 42.0 \\
& $3-5$ & 54 & 23.8 \\
& $6-8$ & 48 & 18.1 \\
& 9 and above & 26 & 16.0 \\
\hline \multirow{5}{*}{ Origin of business } & Started from scratch with ERM & 11.7 \\
& Purchased from the founder with ERM & 45 & 16.5 \\
& Reviving Existing business with ERM & 7 & 41.9 \\
& Inherent from a family member & 93 & 2.3 \\
& Partnership & & 31.6 \\
\hline
\end{tabular}

\section{Measurement Reliability and Variance}

Information of some constructs was collected from the same respondents; hence a common method bias may occur (see [9]). The unrelated factor analysis was adopted for all variables used in the study to control the number of factors; hence, if a single factor emerged from the factor analysis, this indicates that the data suffered from a common method variance problem [44]. As shown in Table 2, the reliability was measured through the coefficient alpha value of all constructs which exceed the 0.70 level and this indicates a good fit. The coefficient alpha for COVID-19 ERM is 0.851 and that of entrepreneurial activity 0.789 respectively. A good fit of the measurement model to the data shows that as hypothesized, all items load significantly on one underlying latent variable. The table indicates the means, S.D variance and correlations of the variables, initial analysis of the data as well as a test for homoscedasticity. Items adopted for COVID-19 were (5) and this was loaded as a single construct during the principal component analysis (PCA) test for factor loading. It also has a 0.838 for KaiserMeyer-Olkin (KMO) test for sampling adequacy, with a chi-square value of 2245.734: d.f. $=15$ and $p=0.000$ all of which indicates a sampling size used to derive the factor loadings has a fit and that the expected scale for measuring COVID-19 ERM was obtained.

Table 2

Reliability Analysis for Multi-Item Scales (Survey research, 2021)

\begin{tabular}{|c|c|c|c|c|c|c|c|}
\hline \multirow{2}{*}{\multicolumn{2}{|c|}{ VARIABLES }} & \multicolumn{2}{|c|}{ Item statistics } & \multicolumn{4}{|c|}{ Item total Statistics } \\
\hline & & Mean & S.D & $\begin{array}{c}\text { Scale Mean } \\
\text { if item } \\
\text { deleted }\end{array}$ & $\begin{array}{c}\text { Scale vari- } \\
\text { ance if item } \\
\text { deleted }\end{array}$ & $\begin{array}{c}\text { Corrected } \\
\text { Item Total } \\
\text { Correlation }\end{array}$ & $\begin{array}{c}\text { Cronbach's } \\
\text { Alpha }\end{array}$ \\
\hline$X_{1}$ & Financial palliatives & 3.4321 & 1.45615 & 13.7909 & 23.026 & 0.711 & 0.870 \\
\hline & Low interest rate on loan & 3.4495 & 1.21041 & 13.7735 & 24.421 & 0.768 & 0.861 \\
\hline$X_{3}$ & Easy loan asses to micro-enterprises & 3.4321 & 1.41721 & 13.7909 & 23.586 & 0.689 & 0.875 \\
\hline$X_{5}$ & TradeMoni, MarketMoni or FarmerMoni & 3.4843 & 1.53932 & 13.7387 & 21.991 & 0.742 & 0.864 \\
\hline \multicolumn{8}{|c|}{$\begin{array}{ll} & \text { Entrepreneurial Activities: The extent to which your firm engaged in the following activities relating to ERM }\end{array}$} \\
\hline \multicolumn{8}{|c|}{ Innovation } \\
\hline$Y_{11}$ & The new or significant product change & 3.7213 & 1.30317 & 14.5017 & 18.069 & 0.629 & 0.732 \\
\hline$Y_{12}$ & New process & 3.3624 & 1.44153 & 14.3345 & 16.272 & 0.669 & 0.819 \\
\hline & New technology & 3.8223 & 1.36122 & 14.4007 & 16.640 & 0.743 & 0.722 \\
\hline$X_{22}$ & Scope of job creation & 3.3240 & 1.47101 & 14.2718 & 20.730 & 0.668 & 0.934 \\
\hline$X_{23}$ & The intensity of job creation & 3.5610 & 1.25253 & 14.2753 & 20.879 & 0.396 & 0.817 \\
\hline$X_{24}$ & The extent of job creation & 3.5749 & 1.40446 & 13.7944 & 20.080 & 0.690 & 0.853 \\
\hline
\end{tabular}


Table cont'd

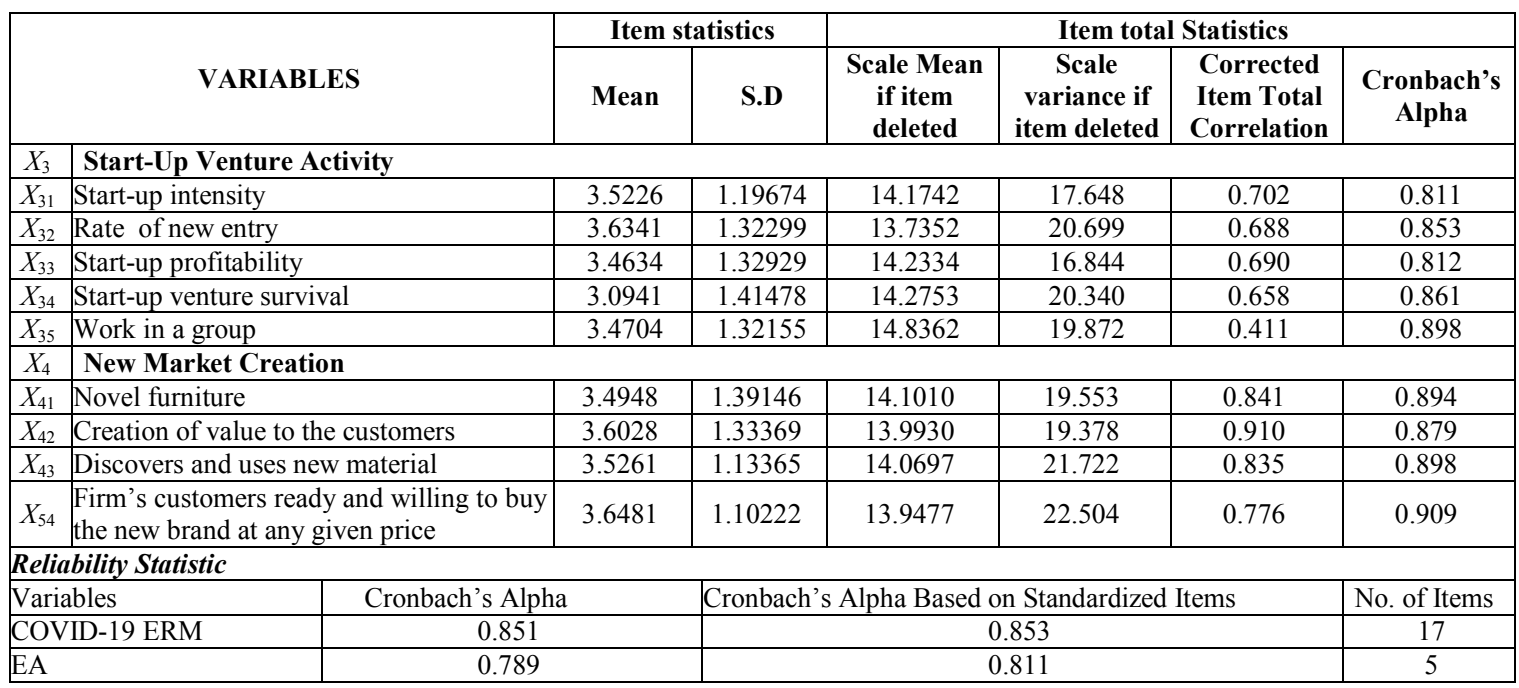

A similar test was analyzed on the dependent variables of EA, a total of five items were used as a proxy for EA (innovation, star-up, job creation, and market creation and knowledge spillover) and each was loaded as a single construct during the PCA test for factor loadings. These are innovativeness loaded as a single construct during PCA test factor. The KMO of 0.779 showed during the test for sampling adequacy with a chi-square value of 4325.375 ; d.f. $=19, p=0.000 .4$ items were adopted for selfemployment also loaded as a single construct during PCA test for factor loadings. The KMO of 0.888 showed during the test for sampling adequacy with chi-square value of 4876.302; d.f. $=19$ and $p=0.000$. Also, start-up venture activity has the KMO of 0.746 which reveals sampling adequacy during the test, with a chi-square value of 3478.213 , d.f. $=19$ and $p=0.000$, while 4 items were used to measure market creation activity loaded as a single construct during PCA factor test. The KMO of 0.7342 during test reveals sampling adequacy with the chi-square value of 4590.431 , d.f. $=19$ and $p=0.000$.

\section{Test of the Hypotheses}

An exploratory correlational research design approach was adopted in the study. This enables us to examine the extent to which two or more variables co-vary. That means that a change in one independent variable is reflected in the change in the dependent variable. It enables data collection at one time since it does not base on future or past performance. This is very important in the study covering the COVID-19 period. Thus, the participants are grouped as a single group rather than as a subcategory during the analysis of the findings of exploratory correlation research. Sarmah and Hazarika (2012) [44] argues on the collection of two scores from each participant representing each variables being studied (COVID-19 and innovative activity, COVID-19 and self-employment activity, COVID-19 and start-up venture activity and COVID-19 and new market creation activity). The hypotheses were tested using Pearson's Product Moment Correlation Analysis using the statistical Package for Social Sciences (SPSS) version 20 (Table 3).

$\mathrm{H}_{01}$ : COVID-19 ERM does not have a significant positive relationship with the innovative activity of entrepreneurs in Nigeria.

Table 3 depicts the correlation between COVID-19 ERM and innovative activity of entrepreneurs in Nigeria. The result of the test of hypothesis shows that there is no significant relationship between COVID-19 ERM and innovative activity of micro-enterprises in Nigeria $(r=0.52, p=0.299)$; hence the null hypothesis $\left(\mathrm{H}_{0}\right)$ cannot be rejected. Therefore, it can be concluded that there is no significant positive relationship between COVID-19 ERM and micro-enterprises innovative activity in Nigeria.

$\mathrm{H}_{0}: \mathrm{H}_{02}$ : COVID-19 ERM does not have a significant positive relation with job creation activity of entrepreneurs in Nigeria.

Table 3 depicts the correlation between COVID-19 ERM and job-creation. The result of the test of hypothesis shows that there is no significant relationship between COVID-19 ERM and job-creation $(r=-0.024, p=0.633)$; hence the null hypothesis $\left(\mathrm{H}_{0}\right)$ cannot be rejected. Therefore, it can be concluded that there is no positive relationship between COVID-19 ERM and job creation activity. 
$\mathrm{H}_{03}$ : COVID-19 ERM does not have a significant positive association with start-up venture activity of entrepreneurs in Nigeria.

Correlation Analysis of COVID-19 ERM vs. Innovativeness (Survey Research, 2021)

\begin{tabular}{|c|c|c|c|}
\hline & & COVID-19 & IV ARIABLES \\
\hline \multirow[t]{3}{*}{ COVID-19 ERM } & Pearson Correlation & 1 & 0.052 \\
\hline & Sig. (2-tailed) & - & 0.299 \\
\hline & $N$ & 0.294 & 0.394 \\
\hline \multirow[t]{3}{*}{ INNOVATION } & Pearson Correlation & 0.052 & 1 \\
\hline & Sig. (2-tailed) & 0.299 & - \\
\hline & $N$ & 0.294 & 0.394 \\
\hline \multirow[t]{3}{*}{ COVID-19 ERM } & Pearson Correlation & 1 & 0.024 \\
\hline & Sig. (2-tailed) & - & 0.633 \\
\hline & $N$ & 0.294 & 0.394 \\
\hline \multirow[t]{3}{*}{ JOB-CREATION } & Pearson Correlation & 0.024 & 1 \\
\hline & Sig. (2-tailed) & 0.633 & - \\
\hline & $N$ & 0.294 & 0.394 \\
\hline \multirow[t]{3}{*}{ COVID-19 ERM } & Pearson Correlation & 1 & -0.194 \\
\hline & Sig. (2-tailed) & - & 0.000 \\
\hline & $N$ & 0.294 & 0.394 \\
\hline \multirow[t]{3}{*}{ START-UP VENTURE } & Pearson Correlation & -0.080 & 1 \\
\hline & Sig. (2-tailed) & 0.000 & - \\
\hline & $N$ & 0.294 & 0.394 \\
\hline \multirow[t]{3}{*}{ COVID-19 ERM } & & 1 & 0.106 \\
\hline & Sig. (2-tailed) & - & 0.076 \\
\hline & $N$ & 0.394 & 0.394 \\
\hline \multirow[t]{3}{*}{ NEW MARKET CREATION } & Pearson Correlation & 0.106 & 1 \\
\hline & Sig. (2-tailed) & 0.076 & - \\
\hline & $N$ & 0.294 & 0.394 \\
\hline
\end{tabular}

Table 3 also depicts the correlation between COVID-19 ERM and start-up venture activity. The result of the test of hypothesis shows that there is no significant relationship between COVID-19 ERM and start-up venture activity $(r=-0.194, p=0.000)$; hence the null hypothesis $\left(\mathrm{H}_{0}\right)$ cannot be rejected. Therefore, it can be concluded that there is no significant relationship between COVID-19 ERM and microenterprises start-up venture activity.

$\mathrm{H}_{0}$ : COVID-19 ERM does not have a significant positive relationship with COVID-19 ERM and micro-enterprises market creation in Nigeria.

Table 3 depicts the correlation between COVID-19 ERM and new market creation. The result of the test of hypothesis shows that there is no significant relationship between COVID-19 ERM and new market creation activity $(r=0.106, p=0.076)$; hence the null hypothesis $\left(\mathrm{H}_{0}\right)$ cannot be rejected. Therefore, it can be concluded that there is no significant relationship between COVID-19 ERM and new market creation.

\section{Discussion, Conclusion and Suggestions}

Using the data gathered on COVID-19 ERM and EA, a Pearson Product Moment correlation was conducted using the SPSS 20 to evaluate the null hypotheses that there is on a significant positive relationship between COVID-19 ERM and innovation, self-employment, start-up venture, and market creation entrepreneurial activities of micro-enterprises in the six Geopolitical zones in Nigeria with the sample of $(n=294)$. Generally, the analysis showed significant evidence to accept the null hypotheses. It was therefore concluded that there COVID-19 ERM does not have a significantly positive relationship with entrepreneurial activity. This study agrees with the finding of [45].

Very few countries like the UK, India, Portugal and Germany are emphasizing helping the MSME. Nigerian ERM has no emphases to micro financing besides, almost all the ERM offered to micro-businesses are like a token gesture, rather than a serious effort, and hence it did not significantly relate to the micro-business EA.

One expects that with the ERM, there will be a substantial revival and new start-up ventures. However, Dube, 2020 [36] observed that the monetary measures put in place by Nigeria government to support some important sectors of the economy failed to lessen the effect of the pandemic from eco- 
nomic crises The short term impact of lockdowns and curtail measure policies have a retrogressive effect on businesses, breaking supply chains, and prompting a shrinkage in total demands, hence, the bankruptcy rate rises and start-up firms' formation rate declined. This, therefore, suggests that firms' operational activities like innovation, new market creation, job creation are not exempted from decline, too. EA is the internal action of firms that translate to wealth externally. Self-employment is important for start-up ventures, innovation, new job creation and new market creations. Fairlie (2020) [5] and Lerner (2020) [12] argued that the long-run economic consequences of the pandemic can lead to a permanent decline in the rate of start-up, growth of businesses and hence job creation and innovation.

In Nigeria, the entrepreneurs, businesses and other macro and microeconomic indicators are still showing a headwind recovery of the 2006 depression talk less of the long term effect of COVID-19 and oil crack impact. The economic recovery could be sluggish and long-term, L-shaped, reduced EA and can shatter the labour market [46]. The result is therefore a piece of clear empirical evidence that the COVID-19 recovery shape of Nigeria falls under the L-shape [3, 21]. Munoz et al (2020) [16] and Naude (2020) [10] also opined that permanent decline in EA will deepen the effect and cause future pandemic hence making a country more vulnerable than the COVID-19. Adequate ERM and honest implementation can result in the changing ways micro-businesses view and approach different aspects of businesses activities and economic order. It can motivate high opportunistic during the pandemic, pivoting their businesses through some kind of entrepreneurial self-employed, start-up ventures, innovation and new market creation and redirecting existing knowledge, skill, people and network to new needs that have emerged [42]. This implies that if adequate policies were not put place and implemented, it will take a long period to close this gap. The Nigeria government should put the extra plan in place to ensure the total and honest implementation of adequate ERM, especially on the intervention funds and grants accrued to micro businesses; this should encourage high EA (self-employment, startup venture, job creation and new market creation).

\section{REFERENCES}

1. Giones F., Brem A., Pollack J. M., Michaelis T. L., Klyver K., Brinckmann J. Revising Entrepreneurial Action in Response to Exogenous Shocks: Considering the COVID-19 Pandemic. Journal of Business Venturing Insights. Elsevier Ltd., 2020, no. 14 (November). Available at: http://www.DOI:10.1016/j.jbvi.2020.e00186 (accessed: 01.11.2020).

2. WHO (2020). WHO Coronavirus Disease (COVID-19) Dashboard, World Health Organisation. Available at: https://covid19. who.int/?gclid=CjwKCAjw (accessed: 01.09.2020).

3. IMF (2020). World Economic Outlook Update, June. International Monetary Fund. Washington DC. Available at: https://www.imf.org/en/Publications/WEO (accessed: 01.11.2020).

4. World Bank (2015). Small and Medium Enterprises (SMEs) Finance. Available at: http://www.worldbank.org/en/topic/financialsector/brief/smes-finance.print (accessed: 01.10.2020).

5. Fairlie R. The Impact of Covid-19 on Small Business Owners: Evidence of Early Stage Losses from the April 2020 Current Population Survey. NBER Working Paper. National Bureau of Economic Research, 2020, no. 27309. Available at: http://www.nber.org/papers/w27309 (accessed: 01.10.2020).

6. Central Bank of Nigeria. Guideline for the Operations of the Agricultural. Small and Medium Enterprises Investment Scheme (AGSMEIS), 2017. Available at: https://nairametrics.com/wp content/uploads/ 2020/07/AGSMEIS-Guidelines-Revised-version2-Resolutions-21-final-1.pdf (accessed: 01.10.2020).

7. SMEDAN and National Bureau of Statistics Collaborative Survey: Selected Findings. 2013. Available at: https://www.msmehub.org/article/2020/09/smedan-and-national-bureau-of-statistics-collaborative-survey2013 (accessed: 01.09.2020).

8. Obunike C. F., Udu A. A. Technological Innovativeness and Growth: A Study of Small Scale Manufacturing Firms in Lagos State. Economics of Development, 2018, vol. 17, iss. 4, pp. 1-15.

9. Enhancing the Contributions of SMEs in A Global and Digitalised Economy. OECD, Council Paris, 2017. Pp. 7-8. Available at: https://www.oecd.org/industry/C-MIN-2017-8-EN.pdf (accessed: 01.11.2020).

10. Naudé W. Entrepreneurial Recovery from COVID-19: Decentralization, Democratization, Demand, Distribution, and Demography. Discussion Paper Series with Aachen University, IZA, Maastricht School of Management and University of Leiden IZA - Institute of Labor Economics, 2020. Available at: http://ftp.iza.org/dp13436.pdf (accessed: 01.11.2020).

11. Fornaro L., Wolf M. Covid-19 Coronavirus and Macroeconomic Policy. 2020. Available at: https://ideas.repec.org/p/bge/wpaper/1168.html (accessed: 01.01.2020).

12. Lerner J. Government Incentives for Entrepreneurship. NBER Working Paper. National Bureau of Economic Research, 2020, no. 26884. Available at: http://www doi 10.3386/w26884 (accessed: 01.11.2020). 
13. Boone L. OECD Economic Outlook: The World Economy on a Tightrope. OECD, 11 June, 2020. Available at: https://www.oecd.org/economic-outlook/june-2020/ (accessed: 01.10.2020).

14. Van-Stel A., Carree M., Thurik R. The Effect of Entrepreneurial Activity on National Economic Growth. Small Business Economics, 2005, no. 24 (3), pp. 311-321.

15. Wennekers S., Van Stel A., Carree M., Thurik A. R. The Relationship between Entrepreneurship and Economic Development: Is it U-shaped? Foundations and Trends in Entrepreneurship, 2010, no. 6 (3), pp. 167-237.

16. Munoz P., Naude W., Williams T., Rodrigo F. Reorienting Entrepreneurial Support Infrastructure to Tackle a Social Crisis: A Rapid Response. Journal of Business Venturing Insights, 2020, no. 14 (November), pp. 1-7.

17. Obunike C. F. Entrepreneurship, Small Scale Enterprises and Employment. Journal of Research in National Development, 2016, vol. 14 (2), pp. 93-101.

18. GEM wiki (2017). How GEM Defines Entrepreneurship. Global Entrepreneurship Monitor. Available at: http://www.gemconsortium.org/wiki/1149 (accessed: 01.10.2020).

19. Zimmerer T. W., Scarbourough N. M. Essentials of Entrepreneurship and Small Business Management. Upper Saddle River, N.J., Pearson/Prentice Hall, 2005. Available at: https://kupdf.net/download/essentials-ofentrepreneurship-and-small-business-management_5a2d209ae2b6f50f58893f49_pdf (accessed: 01.11.2020).

20. Nasiri N., Hameli N. Entrepreneurship Driven By Opportunity and Necessity: Effects of Educations, Gender and Occupation in MENa. Asian Journal of Business Research, 2019, vol. 8, iss. 2, 20, pp. 57-71.

21. Start-ups in the Time of COVID-19: Facing the Challenges, Seizing the Opportunities. OECD, Paris, 13 May, 2020. Available at: https://www.imf.org/en/Publications/WEO (accessed: 01.09.2020).

22. Kirzner I. Entrepreneurial Discovery and the Competitive Market Process: An Austrian Approach. Journal of Economic Literature, 1997, iss. 35, pp. 60-85.

23. Ahmad N., Seymour R. G. Defining Entrepreneurial Activity: Definitions Supporting Frameworks for Data Collection. OECD Statistics Working Papers, 2008/01. Available at: https://doi.org/10.1787/18152031 (accessed: 01.10.2020).

24. Bogenhold D., Heinonen J., Akola E. Entrepreneurship and Independent Professional: Social and Economic Logics. Journal of International Advanced in Economics Research, 2014, no. 20 (3), pp. 295-310.

25. Wiklund J., Shepherd D. Entrepreneurial Orientation and Small Business Performance and Configurational Approach. Journal of Business Venture, 2005, no. 20 (5), pp. 71-95.

26. Suddaby R., Bruton G. D., Steve X. S. Entrepreneurship through a Qualitative Lens: Insight on the Construction and / or Discovery of Entrepreneurial Opportunity. Journal of Business Venturing, 2015, no. 30, pp. 1-10.

27. Gruber M., MacMillan I. C., Thompson J. D. Escaping the Prior Knowledge Corridor: What Shape the Number and Variety of Market Opportunities Identified before Market Entry of Technology Start-ups? Journal of Organizational Science, 2013, no. 24 (1), pp. 280-300.

28. Chepurenko A. Entrepreneurship Theory: New Challenges and Future Prospects. Foresight-Russia, 2015, no. 9 (2), pp. 44-57.

29. Davisson P. A General Theory of Entrepreneurship: The Individual - Opportunity Nexus. Elgar, Cheltenham, UK and Northampton, MA. Entrepreneurial opportunities and the entrepreneurship nexus: A reconceptualization. Journal of Business Venturing, 2004, no. 30 (9), pp. 674-695.

30. Sedlacek P., Sterk V. Start-ups and Employment Following the COVID-19 Pandemic: A Calculator. CEPR Discussion Paper, 2020, no. DP14671. Available at: https://ideas.repec.org/p/cpr/ceprdp/14671 (accessed: 01.10.2020).

31. Gauthier J., Penzel M., Morelix A. This is What COVID-19 Did to Start-Ups in China. World Economic Forum, 07 May, 2020. Available at: https://www.weforum.org/agenda/2020/05/covid-19-s-coronavirus-startupschina-funding/ (accessed: 01.11.2020).

32. Bartik A., Bertrand M., Cullen Z., Glaeser E., Luca M., Stanton C. How Are Small Businesses Adjusting to COVID-19? Early Evidence from a Survey NBER Working Paper. National Bureau of Economic Research, 2020, no. 26989. Available at: http://www.nber.org/papers/w26989 (accessed: 01.11.2020).

33. Djankov S. Europe's Pandemic Price Tag to Keep Firms Afloat. Testimony before the Members of the Committee on Economic and Monetary Affairs of the European Parliament. 30 April, 2020. Available at: https://www.piie.com/commentary/testimonies/europes-pandemic-price-tag-keep-firms-afloat (accessed: 01.09.2020).

34. Carlsson-Szlezak P., Reeves M., Swartz P. Understanding the Economic Shock of Coronavirus. Harvard Business Review, 27 March, 2020. Available at: https://hbr.org/2020/03/understanding-the-economic-shock-ofcoronavirus (accessed: 01.03.2020).

35. GDA (Global Data Analysis), 2020. Coronavirus (COVID-19) Executive Briefing. Global Data. Available at: https://www.business.att.com/content/dam/attbusiness/briefs/att-globaldata-coronavirus-executivebriefing.pdf (accessed: 01.10.2020).

36. Dube A. Filling the Holes in Family and Business Budgets: Unemployment Benefits and Work Sharing in the Time of Pandemics. Policy Brief 24: Economics for Inclusive Prosperity. March, 2020. Available at: https://eig.org/news/main-street-rescue-and-resiliency-program (accessed: 01.10.2020). 
37. Balloch C., Djankov S., Gonzalez-Uribe J., Vayanos D. A Restart Procedure to Deal with COVID-19. COVID-19 in Developing Economies. London, Centre for Economic Policy Research, 2020. Pp. 266-276.

38. Alon T., Kim M., Lagakos D., Van Vuren M. How Should Policy Responses to the COVID-19 Pandemic Differ in the Developing World? NBER Working Paper. National Bureau of Economic Research, 2020, no. 27273. Available at: https://dx.doi.org/10.1787/243164686763 (accessed: 01.09.2020).

39. Ferreira J. J., Ratten V., Dana L. P. Knowledge Spill over-Based Strategic Entrepreneurship. International Entrepreneurship Management Journal, 2017, no. 13, pp. 161-172.

40. Obunike C. F. Employees' Career Transition and Growth: A Study of Women-Owned Micro Businesses in Balogun Market, Lagos, Nigeria. Journal of Economics and Business, 2018, no. 32, pp. 209-227.

41. Acs Z. J., Autio E., Szerb L. National Systems of Entrepreneurship: Measure Issues and Policy implications. Research Policy, 2014, no. 43 (3), pp. 476-494.

42. Kuckertz A., Braendle L., Gaudig A., Hinderer S., Reyes C. A. M., Prochotta A., Steinbrink K. M, Berger E. S. C. Start-ups in Times of Crisis - A Rapid Response to the COVID-19 Pandemic. Journal of Business Venturing Insights, 2020, iss. e00169, pp. 1-13.

43. Neneh B. N., Van Z. J. Entrepreneurial Orientation and Its Impact on Firm Growth amongst SMEs in South Africa. Problems and Perspectives in Management, 2017, no. 15 (3), pp. 166-178.

44. Sarmah H. K., Bora Hazarika B. Determination of Reliability and Validity Measures of a Questionnaire. Indian Journal of Education and Information Management, 2012, vol. 1, iss. 11, pp. 508-517.

45. Aladejebi O. Managing Small Businesses in Nigeria during Covid-19 Crisis: Impact and Survival Strategies. IOSR Journal of Business and Management (IOSR-JBM), 2020, no. 22 (8), pp. 24-34.

46. Gregory V., Menzio G., Wiczer D. Pandemic Recession: L or V-Shaped? NBER Working Paper. National Bureau of Economic Research, 2020, no. 27105. Available at: https://www.nber.org/papers/w27105 (accessed: 01.11.2020).

The article submitted to the editors 02.03 .2021

\title{
INFORMATION ABOUT THE AUTHOR
}

Obi Chinazor Franca - Doctor of Management Sciences; Senior Lecturer of the Department of Business Administration, Faculty of Management Sciences; Alex-Ekwueme Federal University Ndufu-Alike, Ikwo; Nigeria, 1010 Abakaliki, Ebonyi State; ladyfranca8@gmail.com.

\section{$\longrightarrow$ \\ МЕРЫ ЭКОНОМИЧЕСКОГО РЕАГИРОВАНИЯ \\ И ПРЕДПРИНИМАТЕЛЬСКАЯ ДЕЯТЕЛЬНОСТЬ В ПЕРИОД ПАНДЕМИИ СОVID-19 НА ПРИМЕРЕ МИКРОПРЕДПРИЯТИЙ НИГЕРИИ}

\author{
Оби Чиназор Франка \\ Федеральный университет Ндуфу-Алик, Икво, \\ Штат Эбоньи, Нигерия
}

\begin{abstract}
В Нигерии с 2009 г. наблюдался экономический упадок как следствие мирового финансового кризиса, а в 2016 г. произошел обвал мировых цен на нефть. Постепенно экономика Нигерии восстанавливалась до наступления чрезвычайной ситуации, связанной с пандемией COVID-19 и мерами по ее ограничению. Во многих частных и государственных компаниях страны произошли массовые увольнения рабочих, оставшимся была сокращена заработная плата. Микропредприятиям и молодым начинающим специалистам в этот период затруднительно поддерживать деловую активность вследствие недостатка средств для самозанятости, создания новых предприятий, внедрения инноваций или новых рыночных возможностей. С помощью Центрального банка правительство Нигерии приняло определенные денежно-
\end{abstract}


кредитные и фискальные меры, названные мерами экономического реагирования. Проведено изучение взаимосвязи между мерами экономического реагирования в условиях пандемии и предпринимательской деятельностью микропредприятий. Отмечено, что меры экономического реагирования по борьбе с COVID-19 предполагают внедрение инноваций, самозанятости, возникновение новых фирм и создание новых рынков для микропредприятий в Нигерии. С помощью программы Pearson Product Moment Correlation проанализированы результаты исследовательского опроса на 294 микропредприятиях (розничная торговля, сфера информационных технологий, производственная сфера и ремесленники) в шести геополитических зонах Нигерии. Результат эмпирически доказывает, что меры экономического реагирования не имеют существенной положительной связи с предпринимательской деятельностью микробизнеса в Нигерии. Выдвинуто предположение, что многие микропредприятия не получили доступа к мерам экономического реагирования или не приступили к предпринимательской деятельности. Подчеркивается важность государственной поддержки микробизнеса, а также предлагаются новые измерения показателей экономической деятельности микропредприятий.

Ключевые слова: меры экономического реагирования в борьбе с COVID-19, инновации, самозанятость, новые предприятия, создание новых рынков.

Для цитирования: Оби Чиназор Франка. Меры экономического реагирования и предпринимательская деятельность в период пандемии COVID-19 на примере микропредприятий Нигерии // Вестник Астраханского государственного технического университета. Серия: Экономика. 2021. № 2. C. 140-156. DOI: 10.24143/2073-5537-2021-2-140-156.

\section{СПИСОК ЛИТЕРАТУРЫ}

1. Giones F., Brem A., Pollack J. M., Michaelis T. L., Klyver K., Brinckmann J. Revising Entrepreneurial Action in Response to Exogenous Shocks: Considering the COVID-19 Pandemic // Journal of Business Venturing Insights. Elsevier Ltd. 2020. N. 14 (November). URL: http://www.DOI:10.1016/j.jbvi.2020.e00186 (дата обращения: 01.11.2020).

2. WHO (2020). WHO Coronavirus Disease (COVID-19) Dashboard, World Health Organisation. URL: https://covid19.who.int/?gclid=CjwKCAjw (дата обращения: 01.09.2020).

3. IMF (2020). World Economic Outlook Update, June. International Monetary Fund. Washington DC. URL: https://www.imf.org/en/Publications/WEO (дата обращения: 01.11.2020).

4. World Bank (2015). Small and Medium Enterprises (SMEs) Finance. URL: http://www.worldbank.org/en/topic/financialsector/brief/smes-finance.print (дата обращения: 01.10.2020).

5. Fairlie R. The Impact of Covid-19 on Small Business Owners: Evidence of Early Stage Losses from the April 2020 Current Population Survey // NBER Working Paper. National Bureau of Economic Research. 2020. N. 27309. URL: http://www.nber.org/papers/w27309 (дата обращения: 01.10.2020).

6. Central Bank of Nigeria. Guideline for the Operations of the Agricultural // Small and Medium Enterprises Investment Scheme (AGSMEIS). 2017. URL: https://nairametrics.com/wpcontent/uploads/ 2020/07/AGSMEIS-Guidelines-Revised-version2-Resolutions-21-final-1.pdf (дата обращения: 01.10.2020).

7. SMEDAN and National Bureau of Statistics Collaborative Survey: Selected Findings. 2013. URL: https:/www.msmehub.org/article/2020/09/smedan-and-national-bureau-of-statistics-collaborative-survey-2013 (дата обращения: 01.09.2020).

8. Obunike C. F., Udu A. A. Technological Innovativeness and Growth: A Study of Small Scale Manufacturing Firms in Lagos State // Economics of Development. 2018. Vol. 17. Iss. 4. P. 1-15.

9. Enhancing the Contributions of SMEs in A Global and Digitalised Economy // OECD, Council Paris, 2017. P. 7-8. URL: https://www.oecd.org/industry/C-MIN-2017-8-EN.pdf (дата обращения: 01.11.2020).

10. Naudé $W$. Entrepreneurial Recovery from COVID-19: Decentralization, Democratization, Demand, Distribution, and Demography. Discussion Paper Series with Aachen University, IZA, Maastricht School of Management and University of Leiden IZA - Institute of Labor Economics, 2020. URL: http://ftp.iza.org/dp13436.pdf (дата обращения: 01.11.2020).

11. Fornaro L., Wolf M. Covid-19 Coronavirus and Macroeconomic Policy. 2020. URL: https://ideas.repec.org/p/bge/wpaper/1168.html (дата обращения: 01.01.2020).

12. Lerner J. Government Incentives for Entrepreneurship // NBER Working Paper. National Bureau of Economic Research. 2020. N. 26884. URL: http://www doi 10.3386/w26884 (дата обращения: 01.11.2020).

13. Boone L. OECD Economic Outlook: The World Economy on a Tightrope // OECD, 11 June, 2020. URL: https://www.oecd.org/economic-outlook/june-2020/ (дата обращения: 01.10.2020). 
14. Van-Stel A., Carree M., Thurik R. The Effect of Entrepreneurial Activity on National Economic Growth // Small Business Economics. 2005. N. 24 (3). P. 311-321.

15. Wennekers S., Van Stel A., Carree M., Thurik A. R. The Relationship between Entrepreneurship and Economic Development: Is it U-shaped? // Foundations and Trends in Entrepreneurship. 2010. N. 6 (3). P. 167-237.

16. Munoz P., Naude W., Williams T., Rodrigo F. Reorienting Entrepreneurial Support Infrastructure to Tackle a Social Crisis: A Rapid Response // Journal of Business Venturing Insights. 2020. N. 14 (November). P. 1-7.

17. Obunike C. F. Entrepreneurship, Small Scale Enterprises and Employment // Journal of Research in National Development. 2016. Vol. 14 (2). P. 93-101.

18. GEM wiki (2017). How GEM Defines Entrepreneurship. Global Entrepreneurship Monitor. URL: http://www.gemconsortium.org/wiki/1149 (дата обращения: 01.10.2020).

19. Zimmerer T. W., Scarbourough N. M. Essentials of Entrepreneurship and Small Business Management. Upper Saddle River, N.J.: Pearson/Prentice Hall, 2005. URL: https://kupdf.net/download/essentials-of-entrepreneurship-andsmall-business-management_5a2d209ae2b6f50f58893f49_pdf(дата обращения: 01.11.2020).

20. Nasiri N., Hameli N. Entrepreneurship Driven By Opportunity and Necessity: Effects of Educations, Gender and Occupation in MENa // Asian Journal of Business Research. 2019. Vol. 8. Iss. 2, 20. P. 57-71.

21. Start-ups in the Time of COVID-19: Facing the Challenges, Seizing the Opportunities // OECD, Paris, 13 May, 2020. URL: https://www.imf.org/en/Publications/WEO (дата обращения: 01.09.2020).

22. Kirzner I. Entrepreneurial Discovery and the Competitive Market Process: An Austrian Approach // Journal of Economic Literature. 1997. Iss. 35. P. 60-85.

23. Ahmad N., Seymour R. G. Defining Entrepreneurial Activity: Definitions Supporting Frameworks for Data Collection // OECD Statistics Working Papers. 2008/01. URL: https://doi.org/10.1787/18152031 (дата обращения: 01.10.2020).

24. Bogenhold D., Heinonen J., Akola E. Entrepreneurship and Independent Professional: Social and Economic Logics // Journal of International Advanced in Economics Research. 2014. N. 20 (3). P. 295-310.

25. Wiklund J., Shepherd D. Entrepreneurial Orientation and Small Business Performance and Configurational Approach // Journal of Business Venture. 2005. N. 20 (5). P. 71-95.

26. Suddaby R., Bruton G. D., Steve X. S. Entrepreneurship through a Qualitative Lens: Insight on the Construction and / or Discovery of Entrepreneurial Opportunity // Journal of Business Venturing. 2015. N. 30. P. 1-10.

27. Gruber M., MacMillan I. C., Thompson J. D. Escaping the Prior Knowledge Corridor: What Shape the Number and Variety of Market Opportunities Identified before Market Entry of Technology Start-ups? // Journal of Organizational Science. 2013. N. 24 (1). P. 280-300.

28. Chepurenko A. Entrepreneurship Theory: New Challenges and Future Prospects // Foresight-Russia. 2015. N. 9 (2). P. 44-57.

29. Davisson P. A General Theory of Entrepreneurship: The Individual - Opportunity Nexus. Elgar, Cheltenham, UK and Northampton, MA // Entrepreneurial opportunities and the entrepreneurship nexus: A reconceptualization. Journal of Business Venturing. 2004. N. 30 (9). P. 674-695.

30. Sedlacek P., Sterk V. Start-ups and Employment Following the COVID-19 Pandemic: A Calculator // CEPR Discussion Paper. 2020. N. DP14671. URL: https://ideas.repec.org/p/cpr/ceprdp/14671 (дата обращения: 01.10.2020).

31. Gauthier J., Penzel M., Morelix A. This is What COVID-19 Did to Start-Ups in China. World Economic Forum. 07 May, 2020. URL: https:/www.weforum.org/agenda/2020/05/covid-19-s-coronavirus-startups-chinafunding/ (дата обращения: 01.11.2020).

32. Bartik A., Bertrand M., Cullen Z., Glaeser E., Luca M., Stanton C. How Are Small Businesses Adjusting to COVID-19? Early Evidence from a Survey // NBER Working Paper. National Bureau of Economic Research. 2020. N. 26989. URL: http://www.nber.org/papers/w26989 (дата обращения: 01.11.2020).

33. Djankov S. Europe's Pandemic Price Tag to Keep Firms Afloat. Testimony before the Members of the Committee on Economic and Monetary Affairs of the European Parliament. 30 April, 2020. URL: https://www.piie.com/ commentary/testimonies/europes-pandemic-price-tag-keep-firms-afloat (дата обращения: 01.09.2020).

34. Carlsson-Szlezak P., Reeves M., Swartz P. Understanding the Economic Shock of Coronavirus // Harvard Business Review. 27 March, 2020. URL: https://hbr.org/2020/03/understanding-the-economic-shock-ofcoronavirus (дата обращения: 01.03.2020).

35. GDA (Global Data Analysis), 2020. Coronavirus (COVID-19) Executive Briefing. Global Data. URL: https://www.business.att.com/content/dam/attbusiness/briefs/att-globaldata-coronavirus-executive-briefing.pdf (дата обращения: 01.10.2020).

36. Dube A. Filling the Holes in Family and Business Budgets: Unemployment Benefits and Work Sharing in the Time of Pandemics. Policy Brief 24: Economics for Inclusive Prosperity. March, 2020. URL: https://eig.org/news/main-street-rescue-and-resiliency-program (дата обращения: 01.10.2020).

37. Balloch C., Djankov S., Gonzalez-Uribe J., Vayanos D. A Restart Procedure to Deal with COVID-19 // COVID-19 in Developing Economies. London: Centre for Economic Policy Research, 2020. P. 266-276. 
38. Alon T., Kim M., Lagakos D., Van Vuren M. How Should Policy Responses to the COVID-19 Pandemic Differ in the Developing World? // NBER Working Paper. National Bureau of Economic Research. 2020. N. 27273. URL: https://dx.doi.org/10.1787/243164686763 (дата обращения: 01.09.2020).

39. Ferreira J. J., Ratten V., Dana L. P. Knowledge Spill over-Based Strategic Entrepreneurship // International Entrepreneurship Management Journal. 2017. N. 13. P. 161-172.

40. Obunike C. F. Employees' Career Transition and Growth: A Study of Women-Owned Micro Businesses in Balogun Market, Lagos, Nigeria // Journal of Economics and Business. 2018. N. 32. P. 209-227.

41. Acs Z. J., Autio E., Szerb L. National Systems of Entrepreneurship: Measure Issues and Policy implications // Research Policy. 2014. N. 43 (3). P. 476-494.

42. Kuckertz A., Braendle L., Gaudig A., Hinderer S., Reyes C. A. M., Prochotta A., Steinbrink K. M, Berger E. S. C. Start-ups in Times of Crisis - A Rapid Response to the COVID-19 Pandemic // Journal of Business Venturing Insights. 2020. Iss. e00169. P. 1-13.

43. Neneh B. N., Van Z. J. Entrepreneurial Orientation and Its Impact on Firm Growth amongst SMEs in South Africa // Problems and Perspectives in Management. 2017. N. 15 (3). P. 166-178.

44. Sarmah H. K., Bora Hazarika B. Determination of Reliability and Validity Measures of a Questionnaire // Indian Journal of Education and Information Management. 2012. Vol. 1. Iss. 11. P. 508-517.

45. Aladejebi O. Managing Small Businesses in Nigeria during Covid-19 Crisis: Impact and Survival Strategies // IOSR Journal of Business and Management (IOSR-JBM). 2020. N. 22 (8). P. 24-34.

46. Gregory V., Menzio G., Wiczer D. Pandemic Recession: L or V-Shaped? // NBER Working Paper. National Bureau of Economic Research. 2020. N. 27105. URL: https://www.nber.org/papers/w27105 (дата обращения: 01.11.2020).

\section{ИНФОРМАЦИЯ ОБ АВТОРЕ}

Оби Чиназор Франка - д-р наук в сфере управления; старший преподаватель кафедры делопроизводства, факультет управленческих наук; Федеральный университет Ндуфу-Алик, Икво; Нигерия, 1010, Абакалики, Штат Эбоньи; ladyfranca8@gmail.com. 